\title{
Author Correction: De novo emergence of adaptive membrane proteins from thymine-rich genomic sequences
}

\author{
Nikolaos Vakirlis, Omer Acar, Brian Hsu, Nelson Castilho Coelho, S. Branden Van Oss, Aaron Wacholder, \\ Kate Medetgul-Ernar, Ray W. Bowman II, Cameron P. Hines, John lannotta, Saurin Bipin Parikh, Aoife McLysaght, \\ Carlos J. Camacho, Allyson F. O'Donnell, Trey Ideker \& Anne-Ruxandra Carvunis
}

Correction to: Nature Communications https://doi.org/10.1038/s41467-020-14500-z, published online 7 February 2020.

The original version of this Article contained an error in the Competing interests section, which incorrectly omitted "T.I. is a cofounder of Data4Cure and has an equity interest. T.I. is on the Scientific Advisory Board of Ideaya BioSciences, Inc., has an equity interest, and receives income. The terms of these arrangements have been reviewed and approved by the University of California San Diego in accordance with its conflict of interest policies". This has been corrected in both the PDF and HTML versions of the Article.

Published online: 04 January 2021

\footnotetext{
(c) (i) Open Access This article is licensed under a Creative Commons Attribution 4.0 International License, which permits use, sharing, adaptation, distribution and reproduction in any medium or format, as long as you give appropriate credit to the original author(s) and the source, provide a link to the Creative Commons license, and indicate if changes were made. The images or other third party material in this article are included in the article's Creative Commons license, unless indicated otherwise in a credit line to the material. If material is not included in the article's Creative Commons license and your intended use is not permitted by statutory regulation or exceeds the permitted use, you will need to obtain permission directly from the copyright holder. To view a copy of this license, visit http://creativecommons.org/licenses/by/4.0/.
}

(c) The Author(s) 2021 